\title{
UNIVERSITYOF
}

FORWARD

THINKING

WESTMINSTER用

WestminsterResearch

http://www.westminster.ac.uk/westminsterresearch

\section{A Migrant Culture on Display: The French Migrant and French Gastronomy in London (19th - 21st centuries)}

Kelly, D.

This is an author's accepted manuscript of an article published in Modern Languages Open, 2016: September 26 Special Issue '"The Material Turn" in Migration Studies'

The published version is available from Liverpool University Press at:

http://www.modernlanguagesopen.org/index.php/mlo/article/view/148

The published version is made available under a Creative Commons Attribution License (CC-BY) that allows others to share the work with an acknowledgement of the work's authorship and initial publication in this journal.

(C) The Author, 2016.

The WestminsterResearch online digital archive at the University of Westminster aims to make the research output of the University available to a wider audience. Copyright and Moral Rights remain with the authors and/or copyright owners.

Whilst further distribution of specific materials from within this archive is forbidden, you may freely distribute the URL of WestminsterResearch: ((http://westminsterresearch.wmin.ac.uk/)).

In case of abuse or copyright appearing without permission e-mail repository@westminster.ac.uk 


\title{
A Migrant Culture on Display: The French Migrant and French Gastronomy in London $\left(19^{\text {th }}-21^{\text {st }}\right.$ centuries $)$
}

\begin{abstract}
The large contemporary French migrant population - currently estimated by the French Consulate at around 300,000-400,000 in the UK, the majority living in London and the South-East - remains 'absent' from studies on migration, and, in a study of migrant food history in Britain, is considered not to have left traces as a migrant community. Over the centuries, the presence of various French communities in London has varied significantly as far as numbers are concerned, but what does not change is their simultaneous 'visibility' and 'invisibility' in accounts of the history of the capital: even when relatively 'visible' at certain historical moments, they still often remain hidden in its histories. At times the French in London are described as a 'sober, well-behaved [...] and law-abiding community'; at other times they 'appeared as a foreign body in the city'. This article reflects on the dynamics at play between a migrant culture associated with high cultural capital (so much so that is often emulated by those who are not French) and the host culture perception of and relationship to it, in order to consider what this may 'mean' for the French (and Francophone) migrant experience. French gastronomy and culinary knowledge is taken as an example of material culture and of cultural capital 'on display' specifically in the activity of dining out, especially in French restaurants, or in those influenced by French gastronomy. The social activity of dining out is replete with displays of knowledge (linguistic, culinary), of cultural literacy, of modes of behaviour, of public identity, and of rituals strictly codified in both migrant and host cultures. Dining out is also an emotional and politically-charged activity, fraught with feelings of suspicion (what is in the food? what does the chef get up to in the kitchen?) and of anxieties and tensions concerning status, class and gender distinctions. This article considers the ways in which the migrant French citizen of London may be considered as occupying an ambiguous position at different times in history, simultaneously possessing cultural capital and needing to negotiate complex cultural encounters in the connections
\end{abstract}


between identity and the symbolic status of food in food production, food purveying and food consumption.

Keywords: French migrants; French gastronomy; London; material culture; migrant identity; cultural capital

Oh, Madame Prunier, you give us fishes which we wouldn't dream of eating anywhere; you call them by a funny French name, and we all adore them! (Prunier 2011, x-xi)

Que se passe-t-il dans une assiette ? Que retrouve-t-on qui exprime des idées, fasse sens et permette un message ? Quelle est la nature de cette matière à réflexion? Quelle emblématique pour l'empire des signes culinaires ? (Onfray, 156) ${ }^{1}$

\section{French food migrates to London: The French migrant and London food culture ${ }^{2}$}

\footnotetext{
1 Translation for meaning: 'What happens on a plate? What is found there which may express ideas, make meaning, formulate a message? What is the nature of this material for reflection? How can the empire of culinary signs be symbolised'? The philosopher Michel Onfray is making explicit reference to Barthes's 'Empire of signs' (1970) and implicit reference to Barthes's methods of analysing cultural myths, their construction and circulation. These methods also underlie the approach taken in this article to representation and meaning.

2 This article explores some of the preliminary research for a larger project which uses French cuisine as the lens through which to analyse the French (and Francophone) experience in the British capital, historically and in the contemporary city: 'being' French in London. It considers French culinary knowledge and practice at work in the city as a material form of identity, of culture and of cultural capital and examines its place in London's constantly evolving culinary landscape: 'eating' French in London. The project brings together for the first time the main events associated with the arrival, developing presence, integration and changing nature of French cuisine and culinary knowledge - and the changing experiences of Frenchmen and women associated with it in London from the nineteenth to the twenty-first centuries. It also examines what reciprocal exchanges between 
In his discussion of the diffusion of French cuisine in a period which saw what has been called 'the triumph of French cuisine' (Ferguson, 2004), John Burnett makes the important point that it is not immediately clear why 'an alien gastronomy, the product of a traditional enemy with whom England had recently fought a long and costly war, should have become adopted as the exemplar of ultimate fashion' (Burnett, 79) amongst the élites of London society. In his social history of 'eating out' in England from the mid-nineteenth century to the turn of the twenty-first, Burnett analyses how new tastes were formed and fashionable eating became 'legitimised as a mark of sophistication and social status', that is to say eating outside the home in hotels, clubs and restaurants where professional chefs were employed. In London this often meant in places staffed partly, or owned, by the French, as proprietors of restaurants in the late nineteenth and early twentieth centuries were often former French chefs (Burnett, 70, 75). ${ }^{3}$ In his comprehensive comparative analysis of food, eating and society in France and England, Stephen Mennell writes that: 'an important consequence of the prestige of French cookery in the higher social circles seems to have been the "decapitation" of English cookery' (Mennell, 206). What evolved, he argues, was a pattern of "culinary "cultural dependency" - the co-existence of native and foreign styles of food with different social connotations' (Mennell, 204). Both Burnett and Mennell chart the complex historical processes of the development of the status of French gastronomy and its reception in England, avoiding the over-simplifications that give any impression of a history

Londoners and the French who live(d) and work(ed) in London tell us about Londoners' perceptions of the French community in the British capital as seen through cultural attitudes towards food and gastronomy. Monograph to be published by Liverpool University Press.

${ }^{3}$ It is important to stress London as the geographical site for this research; London is not the rest of England nor of Britain. Warde and Martens (2000, 88-89) express surprise that the results of their analysis of eating out in Britain (notably with a focus on a northern region, but with comparative 'testing' in Bristol and London) show London to be a very different case indeed. I am not surprised by this. 'London' votes differently, behaves differently and has a more varied population with diverse tastes and attitudes; it has an identity of its own. Contemporary French residents of the city, in interview, often readily accept the identity of 'Londoner' alongside that of French citizen, just as do internal migrants from other parts of the UK. It is currently outside the scope of this study to compare the experience of French migrants in other parts of the UK, notably in its cities, but more comparative work would be useful in the future. 
in which is inscribed the perception of British cuisine 'as an empty space waiting to be "colonised" by influences from abroad - and especially from France, where food is treated with seriousness, even reverence, at both domestic and professional levels and by producers and consumers alike' (Ashley, Hollows, Jones and Taylor, 77, 78). As Mennell writes: 'French and English cookery are not entirely separate things. They have been in mutual contact and influenced each other over a very long period' (Mennell, 18). Nonetheless, what was it about the evolution of London society and culture that made it so receptive to French gastronomy and to what French migrants there had to offer? What was it about French gastronomy that led it to become prized by certain social groups in London, and when? Why food and why French food? When does it become an indicator of what Bourdieu (1984) would come to term 'cultural capital'? What social changes among the London population facilitated this? These are complex questions which are treated by varied food and cultural historians, with various, but not always clear-cut, answers emerging. There was, after all, also a long history of suspicion in England towards French food that predates this dominance in the nineteenth century, and which does not disappear even in this period outside the restricted social circles of élite society and the geographical orbit of London and the Home Counties (Mennell, 187). Denis Saillard (2014), for example, has examined these exchanges, rivalries and inter-relationships in Anglo-French gastronomic relations from the nineteenth century to the present, and a celebrated example is the Londoner Hannah Glasse's denunciation of French chefs and 'French trickery' in her The Art of Cookery Made Plain and Simple (1747), 'though her hostility did not preclude her borrowing some French recipes' (Mennell, 126). Attitudes towards the French more generally were, of course, historically ambiguous, the result of a long, shared, and at times turbulent history, as for example Isabelle and Robert Tombs (2006) demonstrate in the story of the relationship between the French and the British, 
those 'sweet enemies', from the time of Louis XIV onwards. ${ }^{4}$ French historians Diana Cooper-Richet and Michel Rapoport (2006) note that derision and undisguised admiration 'rub shoulders', and reveal the ambiguity of relations between the two countries (CooperRichet and Rapoport, 390). While Robert Gibson (1995, 2004) writes: 'no two other countries have a heritage that has been enriched over so long a period as England and France. And no two other countries have made so powerful and protracted an impact as these two have upon the lives of one another. Over a span of almost a thousand years, no nation has had so many dealings with the English as the French' (Gibson, 304). ${ }^{5}$ In charting these exchanges in culinary terms, it is difficult not to rehearse many of Mennell's convincing arguments and analyses. Amongst these is the moment frequently picked up on by other food and cultural historians as the 'beginning' of the influence of French cuisine in the aftermath of the French Revolution when: 'many of those who had formerly cooked for the French aristocracy sought alternative sources of income in restaurants in London (as well as in Paris and subsequently, New York' (Ashley, Hollows, Jones and Taylor, 77, using Mennell, 135-44). But ambiguities persist. In the eighteenth century 'the food of the English gentry and prosperous farmers, depicted in the English cookery books, enjoyed a prestige of its own to which there was no equivalent at that date in France' (Mennell, 102), and Nicola Humble's (2004) historical analysis of cookery books makes a good case for the confidence of English eighteenthcentury female cookery book writers. These are two crucial points, however. This English food tradition did not develop in the city: "“country" traits showed considerable resilience in England' (Mennell, 130), ${ }^{6}$ while French haute cuisine continued to develop in a specifically courtly context for a century and half longer than in England. This was important for the

\footnotetext{
${ }^{4}$ Isabelle and Robert Tombs write that: 'this relationship is unique in the modern world, not only for its duration and the breadth of its cultural, economic and political ramifications, but also for its global consequences', 686 .

${ }^{5}$ Indeed, the social differentiation symbolised by food in England can be traced as far back as the Normans, with the use of French terms for cooked meat and Anglo-Saxon terms for the live animal.

${ }^{6}$ Mennell attributes this to the higher prestige accorded country life in England (whereas in France, the court nobility disdained the 'noblesse campagnarde' until after the Napoleonic wars).
} 
development of French professional cuisine after the Revolution, which in turn had 'important consequences for English cuisine in the next century' (Mennell, 133). Concurrently, the gap between professional and domestic cookery widened, together with that between male and female cook. As Christopher Driver writes: 'After Waterloo, the climate gradually changed [and the Napoleonic wars receded into memory], and British cooking of the country house kind, represented in the previous century by Eliza Smith, Hannah Glasse and others, began to look old-fashioned. Technically, it belonged to an age that was passing away' (Driver, 4). The professional French male chefs in London restaurants also then wrote cookery books destined for the home, which displaced the domestic cookery books of the eighteenth century written by women. This is coupled with the persistent narrative amongst food historians and writers that good English food is more suited to production on a domestic scale (for example, Driver, 1983). Nonetheless, in the culinary life of London it is cultural exchange rather than displacement that remains evident; for example, the new French restaurants had precedents in the large taverns that had become fashionable for gentlemen in London in the eighteenth century. ${ }^{7}$ Compellingly, 'The expansion of French cuisine fits in closely with changes in the size and structure of fashionable Society in England during the nineteenth century' (Mennell, 208), and with a particular cultural practice:

The wealthiest families - amounting perhaps to about 400 of the greatest landlords were in the habit of spending three or four months in London in the winter and spring of each year. This annual migration to the capital, known as the 'London Season' had begun haphazardly in the early seventeenth century, and was firmly established by the

\footnotetext{
7 The first restaurant established in Paris, in the last years of the ancien regime, was called 'La Grande Taverne de Londres' (opened in 1782 or 1786), during a period of taste for all things English, as an approximate counterpart to the English tavern (Mennell, 137-8). The chef-proprietors of English taverns also published a number of cookery books, for example John Farley's The London Art of Cooking (1783) which was not 'devoid of French influence' although 'overall the impression is still distinctively English', but it did not represent the ‘separate, elite, professional cuisine [...] already evident in France' (Mennell, 99, 100).
} 
eighteenth (F.J. Fisher, 1948); it was to endure throughout the nineteenth and survive into the twentieth. (Mennell, 120)

Numbers swelled from about 400 families in the eighteenth century to about 4000 by end of the nineteenth, and "with the growing number of individuals involved, the required outward manifestations of gentle status became more and more formalised and elaborate' (208). The 'when' of French culinary status becoming established in London appears to crystallise around the need for visible social differentiation at a moment when competing social classes become more closely interdependent, as the middle class grows and diversifies, and as the élite strata of society expands. By the 1880s, the basis of London Society was beginning to widen, and, importantly for the notion of 'display' which frames this article, the public display of French male chefs in London restaurants coincided with the need for new forms of English social display:

With politics and public affairs withdrawn into somewhat more restricted and 'private' circles, and with the enlargement of Society as a whole, the Season and social life of the élite took on a more theatrical air involving social display in relatively more public spheres. The rise of the great hotel restaurants from the $1880 \mathrm{~s}$ [...] is to be understood as part of this development. (Mennell, 211)

In terms of culinary history, a further consequence of this receptivity to French haute cuisine would be the absence of any élite models of English cookery to follow in a market and society now dominated by French professional cookery (Mennell, 211) and by French male chefs. There is, therefore, a complex process of influence, receptivity and exchange at work which appears to revolve around the meeting point of two élite cultures (the refined culture of 
French haute cuisine and that of the English aristocratic, ${ }^{8}$ and then of the upper middle classes engaged in a further emulation of style and taste). Neither, however, is a 'subordinate' group; rather, they work together to create a London French food culture. This is a new complex cultural encounter and cultural formation, used by the English élite to differentiate itself (and sometimes by members to differentiate themselves from one another) socially, and which simultaneously confers status on the French migrant chef. ${ }^{9}$ A new cultural fabric is created in London when these two élite cultures knit together, reaching a peak in the prosperity of late nineteenth- / early twentieth-century London, and with these attitudes towards French cuisine persisting up to and during the Second World War, as will be seen. ${ }^{10}$

What follows here is therefore initially built on two established bodies of research, one in food history, one sociological, both placed here within the context of migration and within the notion of French culinary knowledge as an example of a migrant culture on 'display'. ${ }^{11}$

\section{Setting the scene: 'being' French and 'eating' French in London}

Broadly speaking, French migrants in numbers enough to be remarkable and to have an impact on culture and cultural production, or on certain areas, of the capital, arrived in

\footnotetext{
${ }^{8}$ This was already true in the eighteenth century. Although the following of fashion extended further down the social scale than in other countries (Mennell, 129), French courtly cookery did not - although it was already in vogue in the great London houses.

9 This is in keeping with Mennell whose own analysis uses Norbert Elias's 'figurational' or 'sociogenetic' approach ([1939] 1978), which uses the term 'figuration' to: 'denote patterns in which people are bound together in groups, strata, societies - patterns of interdependence which encompass every form of cooperation and conflict [...]. Within a developing social figuration, modes of individual behaviour, cultural tastes, intellectual ideas, social stratification, political power and economic organisation are all entangled with each other in complex ways which themselves change over time' (Mennell, 15). Cultural Studies is also influenced by this approach (Ashley, Hollows, Jones and Taylor, 2004). I draw, however, rather different conclusions from those of Christopher Driver (1983) who sees the British surrender 'their independence to the culture of the people their armies had defeated' (4) and the 'cultural conquest of the conqueror by the conquered' (5).

${ }^{10}$ These attitudes persisted despite rationing, and in a period when there is in fact more parity between the social classes as far as nutrition is concerned (coupled with abundant testimony of terrible food).

${ }^{11}$ The notion of 'display' is used broadly here as in the context of the 'visual construction of the social' and the 'everyday practices of human display' as defined in the study of visual culture (Mitchell, 2002, 179).
} 
London from the seventeenth century onwards, firstly largely as religious (in the case of the Huguenot Protestant) refugees from persecution and then as political exiles, although there is also evidence of economic migrants amongst these populations. Amongst the political exiles were firstly Royalists escaping the 1789 Revolution and then Napoleon I, followed by socialists, communists, and (in the later nineteenth century) anarchists fleeing subsequent governments following the restoration of the monarchy, the aftermath of the 1830 and 1848 revolutions, Napoleon III's Second Empire (1852 to 1870), the aftermath of the Commune in 1871 and the beginnings of the Third Republic.

With the exception of the Huguenots (whose legacy to English culture, from fine art and highly skilled craftsmanship in a variety of areas to political and financial institutions, is enormous and still not fully recognised), these political refugees of all persuasions largely returned to France at varying times and after various amnesties, although almost all left a legacy of some kind, and in the early twentieth century up to the Second World War there was an identifiable 'French colony' in London (Kelly and Cornick, 2013). Importantly, some of these migrants and exiles, even those whose primary motivation for leaving France was religious, recognised that London represented more secular opportunities, and similarly those with radical politics not only found work in trades, but also opened businesses (a well-known example being a culinary one, the pâtisserie Maison Bertaux in Greek St, Soho, reputedly founded by exiled Communards, which thrives to this day).

The remark from Madame Prunier's 1938 cookery book used as the first epigraph at the opening of this article is rich in the types of cultural perceptions, experiences and assumptions which are key to any study of the place of French food, cooking, restaurants and 
gastronomy ${ }^{12}$ in British culture both for the purveyor and the consumer and, by extension, for the study of the place of the French migrant in London, both historically and today. It was made by one of the English ${ }^{13}$ clients to Prunier's London restaurant and is quoted by Madame Simone Prunier in her foreword to Madame Prunier's Fish Cookery Book (first published in 1938, and notably re-published by Quadrille in their 'Classic Voices in Food' series in 2011). Opened in 1934, Prunier's remained, until it closed in 1976, a very fashionable seafood restaurant in London, 'continuing to offer the classic French dishes described in Fish Cookery' as Jill Norman describes in the introduction to the re-published 2011 edition. ${ }^{14}$ The recipes are drawn from the menus of the restaurant and the book includes chapters with advice on buying fish and 'elementary rules' for cooking fish, for example, 'Fresh-Water Fish', 'Salt-Water Fish', 'Shellfish', and a note on wine and fish. It also includes 'Turtle Frogs - Snails' (chapter 9, towards the end of the book), and these were amongst Prunier's specialities. As Norman notes, 'Turtle was strictly a restaurant preparation and one nearing its final appearance on menus by the end of the 1930s', continuing: 'Frogs' legs and snails have remained popular, and it is now relatively easy to buy either (usually frozen or in cans) to prepare at home' (viii). It would perhaps be as well to caution that they may have remained 'popular' with lovers of French cooking who are confident enough - and sufficiently at ease with the culture of French cuisine - to try that type of cooking at home, and who are aware of

\footnotetext{
${ }^{12}$ Ory (1998) makes an essential point concerning conceptual and terminological problems in this field of study. As he notes, food, cooking, 'restauration' and gastronomy are not synonymous (9-10), although they are often used by writers interchangeably, sometimes leading to confusion in food writing and history. Added to this is the issue that culinary history and practice, and the study of gastronomy, have only been taken 'seriously' and achieved intellectual legitimacy in scholarly research relatively recently. Ory notes (with reservations) Aron, 1973 and Braudel, 1979 as early studies of interest. Ory himself uses the approaches of cultural history and the analysis of systems of representation to examine gastronomy as a form of material culture. It is noteworthy that Ory also wrote the section on 'La Gastronomie' in Nora, 1992, a key text for memory studies. Other works in French on gastronomy to note are Pitte, 1991 and Rambourg, 2010.

13 'English' has been preferred in this historical context. The use of 'British' and 'English' when writing about culture across an historical timespan is, of course, a complex area. As a general guide, 'British' is used here when the context is that of the broader, more inclusive contemporary period; 'English' is used when the historical context suggests a more precisely English audience, reader, customer, etc., in that period, although these judgements are not always clear-cut.

${ }^{14}$ Jill Norman is a linguist, and an editor, publisher and author of books on food. She worked closely with the hugely influential post-war food writer Elizabeth David, and is the literary trustee of the Elizabeth David Estate.
} 
where to buy frogs' legs and snails, even though canned or frozen. It also indicates a further layer of cultural perceptions, experiences and assumptions concerning French cooking, placed this time firmly in the domain of contemporary middle-class British food culture.

These 'frogs and snails' also represent some of the more suspect ingredients of French cooking for many British palates and attitudes, and by extension a way of expressing historical suspicion of the French and of their fashions, culture and tastes more generally, as previously noted. ${ }^{15}$ While reference to the French as the 'Frogs' is still used in British culture with varying degrees of hostility depending on context, in contemporary London it has been taken on knowingly by the French themselves. French journalists, for example, now often use the term 'Frog Valley' to describe the well-established south-west London enclaves of generally wealthy French residents of the city. The name 'Frog Valley' is also given to a London-based French organisation fostering entrepreneurship, start-ups and business development in the UK for French expatriates. ${ }^{16}$ Madame Prunier is alert to these ambiguous attitudes regarding the French, and significantly adds:

Frogs' legs are delicious fare, something like a very tiny chicken, and we shall help to remove a long-standing and popular reproach that the French eat nothing but frogs, if we come to like them ourselves! As for snails, they have to be eaten to be believed, and to those who like them they are as ambrosia. (Prunier 2011, 250)

\footnotetext{
${ }^{15}$ Frogs and snails are also, of course, what some versions of the traditional English rhyme has (nasty) little boys made of (other versions includes 'snips' - a dialect word for eels - and 'slugs') together with 'puppy dogs' tails' as opposed to the 'sugar and spice and everything nice' of which little girls are made, perhaps indicating where English taste preferences lie, and indicative of the sweet puddings for which English cooking is traditionally known. In a wider context, an attitude of suspicion in public perceptions of what goes on in restaurants, and of those who work in them, is a more general one, not confined to attitudes towards the French (although the fact that they are working in/with food may compound it). See Fine, 2009, 41-42.

${ }^{16}$ I am using the term 'expatriates' here as it is that used on the organisation's website; the term used for the various 'London French' itself varies and depends on context, who is using to and to whom it is applied indicating the diverse and changing nature of French migration to the British capital which is difficult to categorise amongst other migrant, economic migrant, exile, self-initiated expatriate groups.
} 
Madame Prunier, a female French migrant restaurateur in a largely male-dominated profession, shows herself to be an accomplished cultural ambassador, placing herself both on the side of the 'deliciousness' of French cooking, and of the English cook and diner, and offering food in cultural exchange as a powerful way of overcoming rejection, fear, mistrust, loathing, prejudices and assumptions about the other. She not only maintains the integrity of her own cultural heritage, a material culture exemplified here in food, but opens it up inclusively to another culture as a shared experience. She therefore exemplifies in many ways the ambiguous position of a French migrant in London as being at once in possession of culinary knowledge and needing to negotiate complex cultural encounters in the connections between identity, food production, food purveying and food consumption; issues which will be returned to in the conclusion.

There also seems to be an important subtext underlying these exchanges between Madame Prunier, her clientele and her readers, which provides a type of 'mirror image' of the use of French gastronomy and dining out as a tool of social differentiation for the nineteenth century English upper and upper-middle classes, as discussed in the opening section of this article. How does the cultural prestige (aligned with what Bourdieu came to term 'cultural capital'), which French gastronomy and the French restaurant and dining experience in the early to mid-twentieth century confer on a French migrant such as Madame Prunier, circulate? Is it extended by association to other French migrants, not only those working directly in the restaurant and food business? ${ }^{17}$ Does it play a significant role in English/British perceptions of them, leading perhaps to a particular view of French migration and to a particular experience of migration for the French? ${ }^{18}$ Is French cultural identity

\footnotetext{
${ }^{17}$ See also Chevrier, 31, on the French seen as 'gastronomes' by those outside France (he notes particularly the 'Anglo-Saxon' press, a particular French term for a certain view of the English-speaking world).

${ }^{18}$ In the contemporary city we also need to ask if this experience is the same or different for the increasing numbers of Francophone migrants; again this aspect forms part of a wider research project more fully referenced in note 2 above.
} 
'marked' to a significant degree by certain types of culinary knowledge and practice? ${ }^{19} \mathrm{~A}$ speculative answer to these last three questions, built on observation and anecdote, ${ }^{20}$ is, for the moment, a qualified 'yes', although to answer with an evidence base requires more primary research.

What one eats (and where one eats it) is tightly connected to identity, politics, ideology (Fine, 2009, xv), and to images of self and other, and is therefore important for all migrant communities. Indeed, the connection between identity and consumption 'gives food a central role in the creation of a community, and we use diet to convey an idea of public identity' (Fine, 1). ${ }^{21}$ As Fine's ([1996], 2009) research into kitchen culture shows, while Bourdieu (1984) uses food consumption in France as an indicator of the cultural capital of the eater, it is also the case that food production is an indicator of the cultural capital of the cook (Fine, 191, 263). What we eat and what we cook - and where and how we it eat it - are markers of identity (hence Bourdieu's interest in the role of cultural and symbolic capital in the process of establishing and displaying distinction). Sociological studies show that the acquisition of knowledge and the capacity to discuss food is used as evidence of the possession of cultural capital and is a way of cultivating social capital (Warde and Martens, 2000, 199), and in contemporary London knowledge of cuisine is increasingly an important element of the cultural literacy of young urban professionals (Fine, 155 using Zulkin, 1991). This suggests a contemporary development of the nineteenth-century phenomenon of French gastronomy being used for social differentiation, although that knowledge now extends far beyond French cuisine and the class make-up is more diverse. What does not change is that identity is bound up with food, or as Jean Anthelme Brillat-Savarin (1755-1826), considered

\footnotetext{
${ }^{19}$ Chevrier (11) again also notes French gastronomy as an important identity marker.

${ }^{20}$ Ory (1998) notes the challenges for scholarly research in incorporating necessarily anecdotal history in this field.

${ }^{21}$ Fine ([1996], 2009) is analysing kitchen culture (in America, in a specific geographical location), but makes a number of essential points regarding the link between food and ideological structures.
} 
one of the founders of the gastronomic essay ${ }^{22}$ in the eighteenth and nineteenth centuries in France, wrote: 'Tell me what you eat and I will tell you what you are.'

\section{Culinary Tales: Food and the French Migrant Experience}

The contemporary large French migrant population - currently estimated by the French Consulate at around 300,000-400,000 in the UK, the majority living in London and the South-East - remains, however, 'absent' from studies on migration, and has only recently been placed within a more complete historical trajectory (Kelly and Cornick, 2013). Similarly, research into the migrant experience and food in the UK is only just developing in a serious way: ${ }^{23}$

While research has begun to emerge on the relationship between food and ethnic identity in the USA it remains, in the case of Britain, in its infancy [...]. The absence of research on the relationship between food and migrant identity remains surprising because $[\ldots]$ the two have close links in Britain. (Panayi, 41)

In the first comprehensive study of the impact of immigration on the transformation of British food since the Victorian period, Panikos Panayi's Spicing up Britain. The Multicultural History of British Food (2008), the French appear to be perceived as 'a-typical' migrants. While Panayi fully recognises the importance of French influence in the nineteenth

\footnotetext{
${ }^{22}$ Ory (1998) makes clear the essential distinction to be made between gastronomy - the 'rules' of eating and drinking and the art of the table - and gastronomic discourse as given form, for example, in the gastronomic essay which is part of the 'code', but which talks about food, cooking and their related practices; the gastronomic writer is not necessarily an accomplished cook. However, it is equally important to be aware that talking (well) about food is a vital part of the gastronomic experience as understood within French culture.

${ }^{23}$ Panayi (2008) notes a couple of exceptions: a collection of essays edited by Pat Caplan in which ethnicity represents a minor theme, Food, Health and Identity (1997); and more importantly Anne Kershen's Food and the Migrant Experience (2002), considered a ground-breaking collection which approaches the subject in a variety of ways including immigrant entrepreneurship, health and ethnicity. Kershen is also, notably for the study of French migrants, the author of Strangers, Aliens and Asians: Huguenots, Jews and Bangladeshis in Spitalfields, 1600-2000 (2005).
} 
century, charting the 'rise of gastronomy' in Britain (79), ${ }^{24}$ and identifying its decline during the twentieth century as food in England became internationalised (26), he goes on to state that the French migrant community 'has left little trace' (42). Historically, his study begins by focusing on the largest migrant communities in London in the nineteenth century - the Irish, the Jewish, and in the Victorian and Edwardian period, the German, which was the most significant 'continental' minority, then virtually eradicated during the First World War (4243). The French are mentioned only briefly here, while a section is devoted to the Italians, and another to the only significant, though tiny, non-European group in the period, the Chinese. Despite Britain's long-established links with India, there was only one short-lived Indian-run eating place in London in the nineteenth century (Ehrman, 78). This 'sidelining' of the French is all the more surprising since the French were historically - and remain today - highly visible in terms of a material culture exemplified in gastronomy, in cooking, in restaurants and the food business, and in food culture. ${ }^{25}$ There is obviously an issue of class at stake here - and this is essential in considering the French as a migrant community. As previously explored, French gastronomy was certainly only known to, and influenced only, the upper classes during the later nineteenth century, and French migrants often worked with and for the upper classes and wealthier middle classes (for example as language and dance teachers, as tutors, milliners, couturiers, and in other service sectors as well as cooks, chefs and waiting staff). Nonetheless, key questions emerge if the French are not considered a significant migrant community in a founding text of migrant food history in Britain. What this surely points to is the difference in the way in which French cuisine and cooking arrived in England, notably in the nineteenth century and primarily in London, combined with the

\footnotetext{
${ }^{24}$ In this discussion he uses Burnett, 2004 and Bowden, 1975.

25 A striking example of this in global terms is that in November 2010 UNESCO conferred Intangible Cultural Heritage status on the French gastronomic meal (Chevrier, 2011 takes this as the starting point for his book). The precision of the 'meal' is important, not French gastronomy itself, although this is a popular perception of the award; it is the practice, ritual and ceremony of the meal that is recognised by the award, whether at home or in a restaurant.
} 
fundamental issue concerning for whom a migrant community provides foodstuffs and cooks, and where migrants themselves eat out. This certainly marks the French experience as different from the trajectories of those other communities analysed by Panayi. Yet, while French gastronomy and culinary knowledge were associated historically with the English upper and upper middle classes, 'Frenchness' is represented and consumed by many different people and in many different ways, as is the case in identity-making by many other migrant groups, particularly in an ever-diversifying global city such as London. ${ }^{26}$

Over the centuries, the presence of various French communities in London has varied significantly as far as numbers are concerned, but what does not change is their simultaneous 'visibility' and 'invisibility' in accounts of the history of the capital: even when very visible at certain historical moments, they still often remain relatively hidden in its histories, a paradox given the cultural culinary capital which is the focus here. ${ }^{27}$ A telling example of the way in which the French were and, current research suggests, still are perceived by Londoners is to be found in a 1901 three-volume conspectus on London life. Several chapters are devoted to immigrant communities (Greeks, Germans and Italians amongst others) that had made London their home. In the pages on the French, the following observation was made:

The French in London form a sober, well-behaved, industrious and law-abiding community. They give very little trouble to the police and law courts, and it is seldom that the name of a French resident obtains an unenviable notoriety in the newspapers. There are about 21,000 French sojourners in England, and about 11,000 of them in the

\footnotetext{
26 A more nuanced picture is needed, obtainable by looking at the French migrant experience in London mediated by social class, generation, and gender.

${ }^{27}$ See, for example, Kelly 2013b. A striking example is that of the Free French in London during World War Two, highly visible on the streets of London, but difficult to track in British social histories of the period; see also Atkin, 2003.
} 
metropolis [they are] not to be found loafing in the neighbourhood of Leicester Square and Piccadilly Circus [...] They are to be found in City offices and warehouses, in workshops and studios, in West End establishments and shops, in schools and private families. (Villars, 133) ${ }^{28}$

Yet, there are equally very different historical perceptions of other French exiles:

Their [outside observers'] growing hostility and the polemics provoked by the anarchists' presence - suspected as well as seen - turned London into a contested space. The novelty that this presence represented must also be stressed, in order to convey the sense of puzzlement expressed by contemporaries - and by the exiles themselves - upon seeing or even just imagining these hundreds of individuals recreating an anarchist 'Petite France' in the streets of Soho and Fitzrovia. Their dismay stemmed from the fear of anarchist terrorism, because of the well-established reputation of the French as dynamitards or bombistes, but also from a culture shock, as these comrades were often described as quintessentially French artisans, settling down in London in the heyday of the Victorian age. The written testimonies left by the French in London as well as the British observers of these groups testify to the same impression of strangeness and otherness, often conveyed by a close attention to details revealing cultural differences and idiosyncrasies. (Bantman 2013, 195-6)

${ }^{28}$ Cited also in Atkin, 185 and Kelly and Cornick, 312. 
While Escoffier was feted at the Savoy, presenting a French gastronomy very much on display, such French political exiles of Soho lived in poverty and represented a very different type of French community in London.

\section{French migrant experience on display: French food as 'cultural capital'}

Throughout the long history of French migration to London up to the present day, and despite the reputation of certain high-profile figures or prominent groups throughout the centuries, the French have therefore not attracted substantial attention as migrants and exiles. This is despite sporadic anti-French feeling which continues to the present (notably in some areas of the British press) but usually directed at the French in France, not at the French in the UK. There were also specific resentments in some trades in which various French migrants worked, at certain political flashpoints, often concerned with historic wars (the Napoleonic era being an obvious example);29 and varying vaguer 'suspicions' concerning the influence of French tastes and fashions, as already discussed.

It is not the aim here to cover in detail here the best-known period of the French migrant experience in its connections with French gastronomy, when French chefs and restaurants became fully established London in the nineteenth century, ${ }^{30}$ but it is obviously essential to give further context to the origins of the association of French migration to London with food, and with French gastronomy. ${ }^{31}$ As Valerie Mars (2013), amongst others,

\footnotetext{
${ }^{29}$ Although the French fleeing the French Revolution and its aftermath were generally welcomed in London.

${ }^{30}$ See, for example, Burnett (2004), 66-98; 137-164.

31 What follows here is, at the moment, largely based on secondary research. One aim of future research is to look beyond the well-known names of French gastronomy in the London of the period to investigate other French migrant experiences; for example, a man such as Adolphe 'Pépé' Cadier who had worked with Escoffier, went on to work at Prunier's (coming out of retirement to help keep the restaurant running when younger chefs and other restaurant staff had to return to France at the beginning of the Second World War). Accounts of the lives of less fortunate French migrants in the early twentieth century are to be found in, for example, the writer and gastronome André Simon's Les Pauvres de France en Angleterre (1919) written by him as a fundraiser during his time as President of The French Benevolent Society (founded in London in 1842 by Comte Alfred d'Orsay at a time when some of the intended beneficiaries had been living a precarious existence in England since the French Revolution). Simon later founded the International Wine and Food Society in London. Trade
} 
has shown, French cooks, chefs and their styles of cooking have had varying influences on London for centuries. ${ }^{32}$ Cookbooks too, in English translation, had a considerable influence, ${ }^{33}$ for example, La Varenne's Le Cuisinier François - published in France in 1651 and then in English in 1653; and earlier Robert May, who published The Accomplisht Cook, or the Art and Mystery of Cookery in 1617, had been sent at the age of ten to learn his trade for five years in Paris (Mars, 218-9). During the seventeenth century 'French cuisine became increasingly popular amongst the middle and upper classes, and new French eating houses offered ragout (highly seasoned stewed meat and vegetables), morels, frogs, snails, sauces and new salads' (Forsyth, 31) in a period which saw a rapid increase in the population of London, and an expansion of catering provision. Major French works continued to be translated throughout the eighteenth century, and nineteenth-century English food writers acknowledged French pioneers, for example the Almanach des Gourmands, edited by A. Grimod de la Reynière (published from 1803 to 1812) and Jean Anthelme Brillat-Savarin's La Physiologie du goût (1825), fundamental texts in the development of French gastronomic discourse (Ory, 1998; and see also note 22). The cookery book became important in the cultural transmission of French food knowledge and practice into English culture, alongside the rise of French haute cuisine in London clubs and restaurants, and the cult of the celebrity chef, the 'face' of a certain type of French migration and very much representative of French gastronomic knowledge on display:

Three major changes occurred in the nineteenth century that altered the experience of eating out in London. French haute cuisine became available to the public for the first

publications such as The Caterer and The London Hotel and Restaurant Employees Gazette published useful and revealing short profiles of chefs and waiters.

${ }^{32}$ One early example is Pero Doulx recorded as working for Henry VIII at Hampton Court (Mars, 217).

${ }^{33}$ See also Panayi (2008) and especially Humble (2004) on the place, dissemination and influences of cookery books. 
time, restaurants created a new venue for eating out, and the hotel was re-invented to provide an environment for entertaining outside the home. These changes laid the foundations for today's experience of eating in restaurants. Only a small percentage of Londoners enjoyed genuine French cooking or eating in restaurants during the nineteenth century, but chefs like Ude, Soyer, Francatelli and Escoffier became household names. Their cookery books demonstrated excitingly different ways of preparing and presenting food. (Ehrman, 69)

The hotel and restaurant trade continued to expand, and French cooks continued to prosper in kitchens and dining rooms, private and public, across the capital. ${ }^{34}$ Throughout the nineteenth century the "cachet of employing a French chef [in households, Mayfair hotels and restaurants, clubs in St James] continued, and is often described as having begun and concluded with two great French chefs: Antonin Carême (1783-1833) and Georges Auguste Escoffier (1847-1935)' (Mars, 224). Although Carême's stay was brief (employed by the Prince Regent from July 1816 to late 1817), his greater legacy is his published works from which a number of recipes were translated into English, and he is called by one of his biographers 'the First Celebrity Chef' (Kelly, 2003).

His influence also endured through Charles Elmé Francatelli (1805-76) who had worked for him in Paris and who became chief cook and maître d'hotel to Queen Victoria, also cooking for clubs and the nobility, and further publishing mass-circulation cookery books for both the middle and working classes, for example The Modern Cook (Mars, 225; Panayi, 22). Francatelli's important contemporary was Alexis Soyer who arrived in London after the July Revolution that removed Charles X in 1830. Chef at the Reform Club, where he

\footnotetext{
${ }^{34}$ Another important influence was that travel to and from the continent also became more widespread after 1860; British travellers returned with new tastes for French cooking, and middle-class French travellers and residents, along with native Londoners, were also catered for in French restaurants and hotels around Leicester Square and Soho (Mars, 221-223).
} 
designed their kitchens using the latest technology and to which he gave guided tours, he also gave well-publicised dinners and banquets. He famously aided Florence Nightingale in the Crimean War, and had earlier created soup kitchens in Dublin which fed the poor during the Irish potato famine (1845-1849), then in London (in Spitalfields) at the government's request. He wrote cookery books aimed at the working classes, The Poor Man's Regenerator (1848) and Soyer's Shilling Cookery for the People (1854). ${ }^{35}$ Soyer also wrote for the middle classes and created The Modern Housewife (1849), a best-seller for the middle-class market.

Like the Reform Club with Soyer, a number of clubs with French chefs opened from the early nineteenth century onwards. Louis-Eustache Ude had been originally been apprenticed in the kitchens of Louis XVI, travelled to England like many cooks and chefs following the break-up of aristocratic French households during the Revolution, and was eventually appointed chef to the fashionable London gambling club, Crockford's, in 1828. Other clubs and hotels with French chefs included Watier's Club, Piccadilly, in 1807, and Grillion's Hotel in Albemarle Street, opened by Alexander Grillion in 1813. Jean Escudier's Pulteney Hotel, Piccadilly, opened in 1814 and Louis Jacquier's Clarendon Hotel in Old Bond Street in 1815. In the same year Jacques Mivart opened a hotel on the corner of Brook St and Davies St which was to become Claridge's in 1896, and Watier's hotel was rebuilt and became first the Coburg and then (as now) the Connaught (Mars, 233-234). The clientèle of Escoffier, also claimed by his biographer as 'the first great star of modern cooking' (James, 2002) included Edward VII as well as the leaders of society and fashion during the period. His partnership with César Ritz at the Savoy established French haute cuisine as an essential part of the luxury hotel.

Apart from restaurants in hotels, the number of French-owned restaurants had increased in the second half of the nineteenth century. Almost all the menus in Lt.-Col N.

35 Panayi (25) sees today's Jamie Oliver representing the contemporary Soyer, for example, with his campaigning for improved diets. 
Newnham-Davis's Dinners and Diners: Where and How to Dine in London (1899) are in French (Mars, 38). Of these a well-known and long-lasting example is the Café Royal, first opened in Glasshouse St in 1865 by Daniel Nicolas Thévenon, then expanding into Regent Street. Another long-established survivor, still open today however changed, is L'Escargot, which opened in 1894 (and where they raised their own snails in the cellar). ${ }^{36}$ Together with the Maison Bertaux, which opened in 1871, these establishments represent a tangible link to very different aspects of the legacy of French migration to London.

There was also however, an association with French food that was not only for the upper-class restaurant diner in the French restaurant's association with London's more bohemian and artistic milieux. In the early twentieth century, Soho and the area north of Oxford Street (later known as Fitzrovia) were key here, with 'small, continental restaurants frequented by artists, philosophers and poets'; and the attraction of restaurants such as the Café Boulogne, Béguinot and Schmidt's in Charlotte Street was not only the bohemian ambience, but also the very cheap meals (Ross 1999b, 89). The prestige and popularity of the French gastronomic expertise continued into the 1920s in élite society also, notably with Xavier Marcel Boulestin who opened the simply named Restaurant Français in Leicester Square in 1925, moving to Covent Garden in 1927 as the Restaurant Boulestin and which remained open until 1986, despite its owner's death in France towards the end of the Second World War. Boulestin is another claimed as the first modern celebrity chef:

Besides offering authentic French haute cuisine, as opposed to the bourgeois and often Italianate version found in Soho, Boulestin wrote a cookery column in Vogue, ran a cookery school at Fortnum and Mason's and in 1937 became the nation's first

\footnotetext{
${ }^{36}$ Kettner's (only recently closed) opened in 1867.
} 
television chef when he recorded the BBC's first cookery programme. (Ross 1999b, 91-92)

His restaurant was also famous for its 'modern Parisian' design with panels painted by Jean Laboureur and Marie Laurencin, and fabric designed by Raoul Dufy, and the display, and indeed theatricality, of this French restaurant is evident. The Restaurants of London (1928) described the space as:

A modern Parisian restaurant in decoration and a luxurious one at that. The carpet is wine colour, the curtains are of patterned yellow brocade; over the mantelpiece is a painting of a dinner table [...] the lounge portion of the room is illuminated and decorated by a square of hanging silk balloon lights. In a prominent place is an immense bottle of 1869 liqueur brandy de la maison, a graceful reminder that the place studies drink equally with meat. ${ }^{37}$ (Hooton-Smith, 47)

Like Madame Prunier's cook book previously referred to, Boulestin's Simple French Cooking for English Homes, first published in 1923, has also been recently republished in Quadrille's 'Classic Voices in Food' series (2011), testament to an enduring appeal of classic French cooking to the British food writing and cookery book market. Jill Norman notes in the introduction: 'Established as the expert on simple French food and cooking, his books paved the way for later 20th century writers [...] He was the most imaginative and liberating food writer of his time. Elizabeth David acknowledged her debt to him' (ix). The food writer and restaurant critic Matthew Fort wrote in The Guardian, 10 November 1999 that: 'The modern cook book began in the 1920s with an immigrant Frenchman, Marcel X Boulestin' (even

\footnotetext{
${ }^{37}$ Prunier's, which opened in 1934, was in the same line of 'fine cuisine and smart design' (as was the Italian
} Quaglino's, also in St James, which opened in 1929). 
though, like Madame Prunier who arrived a little later, it is unlikely that he thought of himself as an 'immigrant').

The importance of such established French (and sometimes only apparently French) restaurants, and therefore of the culinary legacy of the French in London, remains evident within the context of Second World War London and is revealing for two reasons. Firstly, the fact that a new, very different set of French migrants was able to attach itself to the spaces and places of the capital already associated with earlier French migrant communities indicates the established nature of the culture of the now rapidly changing French 'colony'. Secondly, the war is a turning point in British patterns of eating out, and of eating more generally. As John Burnett points out 'one of the strange ironies' of the Second World War is that more people ate out than in any other period of British history (not necessarily for pleasure, frequently out of necessity), and probably did not again until very recently (Burnett, 226)..$^{38}$

The number of London restaurants and hotels associated with the Free French is impressive: the Connaught and the Savoy for de Gaulle, the Rubens, Rembrandt, Hyde Park, Waldorf, Grosvenor, Kensington Palace, Mount Royal at Marble Arch (the list goes on), for figures such as Jean Moulin, Captain Rémy, Muselier, Pierre-Bloch. Historic late nineteenth/ early twentieth-century restaurants mentioned in memoirs, diaries and letters include Soho's Le Berlemont, which is still going strong today in another guise above the 'French Pub' in Dean Street and which was actually Belgian and not French... and was indeed German in origin (being 'French' and not French is an issue which will be returned to in the final section here), and also Chez Victor and Chez Rose, both in Soho, the latter also Belgian and wellknown for its (horse)steak and chips. A novel written in the period also describes the significance of these places:

\footnotetext{
${ }^{38}$ See also Panayi (2008) on changes in British eating habits in the war (95-122), and Driver (1983, 16-37).
} 
Arguing strategy and politics over a restaurant table had proved the salt of their émigré existence. They liked the atmosphere of Soho [...] The French sailors leaning against lampposts ogling the girls, they found an echo of home at Berlemont's where aperitifs were served, continental fashion, and afterwards they would go to their favourite restaurants to be greeted amicably by the patronne. (Henrey, 132) ${ }^{39}$

In other parts of London the grander Prunier's in Mayfair (as previously mentioned), l'Ecu de France, L'Escargot and Le Coq d'Or are mentioned (Kelly 2013a, 315-316). ${ }^{40}$ Strikingly, the effects of the high cultural capital of French knowledge about food and dining, and therefore of apparently 'being French', is exemplified in the account of a young female British volunteer with the Free French Forces and temporary war-time Londoner:

One thing I noticed wherever we [including with male companions] went in the restaurants, with my being in French uniform, it was me the waiters consulted for the choice of dishes, wines, etc., Everyone seems fond of, and strives to emulate the French somehow. Their opinions as regards food, etc., are much respected. I have gained a good deal of assurance through this, and I'm glad. ${ }^{41}$

\footnotetext{
${ }^{39}$ One of a trilogy of novels by Mrs Robert Henrey (Madeleine Henrey, née Gal) set in war-time London which provide a vivid, partially autobiographical, portrait of experiences in the city by a pre-war migrant Frenchwoman married to an Englishman; also cited in Kelly (2013a), 326.

${ }^{40}$ Madame Simone Prunier, the grand-daughter of its founder and whose recipe book provided the epigraph here, wrote an invaluable account of the origins and development of the Prunier restaurants in both Paris and London, La Maison. The History of Prunier's (1957) and her awareness of the importance of the place of the restaurant in a history that extends beyond the gastronomic is evident $(258 ; 273-4)$.

${ }^{41}$ Private Papers of Lesley Boyde (née Gerrard); IWM Documents 270. Originally from Douglas on the Isle of Man, a member of the Free French Corps de Volontaires Françaises in Second World War London, she spent time in France before the war and much preferred life in the French women volunteers' barracks to the training in the British Auxiliary Territorial Service (ATS); she describes in her letters to her family many of her rather good meals, served with wine, at Moncorvo House and later in Hackin House, home to the French women volunteers, both in Ennismore Gardens, Kensington. There is a great deal to extrapolate from this experience and observation; not least it runs counter to the sometimes Francophobic discourse which seeps into British cultural, social and political life in a more or less extreme form both historically and today (even in gastronomic
} 
During the early to mid-twentieth century, the place of French haute cuisine had remained 'secure' as the 'ideal cuisine for élite dining' (Mars, 239). In the 'culinary revolution' since 1945 (Panayi, 124-180), the post-war British culinary landscape would change radically in a comparative short space of time. The taste for French bourgeois cookery nonetheless endured, often based on that from an earlier century, and in fact expanded in the 1950s with the popularity amongst the British middle classes of Elizabeth David's French Country Cooking (1951) and French Provincial Cooking in 1960. In the 1960s, with the growth of a new youth culture and more informality in eating out and social occasions, inexpensive, simpler and less formal French cookery became popular through 'the new bistros' (Mars, 39) whose popularity again also transferred into cook books, and this trend continued. To take but one late twentieth- / early twenty-first-century example of the legacy of a taste for 'simpler' French cooking: Raymond Blanc (again a TV chef as well as a guardian of haute cuisine and owner of cookery schools, brasseries, pâtisseries, following in the footsteps of prestigious French predecessors) with his Simple French Cookery (Step by step to everyone's favourite French recipes). The reader is invited to 'recreate authentic French family cooking in your kitchen with simple-to-follow recipes' and 'enjoy the unfussy simplicity of Moules marinières or French onion soup, or try dinner-party favourites such as Coq au vin and Gratin dauphinois' (Blanc, back cover). Furthermore: 'This book will dispel the myth that French cuisine is difficult to master' (Blanc, 7), echoing the earlier French migrant Marcel Boulestin writing that 'French cooking is not, as some people seem to think, complicated, rich and expensive. [...] Most of the recipes it [this cookery book] contains are simple and the dishes easy to make' (Boulestin, xii-xiii). ${ }^{42}$ French food knowledge and

matters). This experience described by Lesley Gerrard is partially to do with the relationship between the Free French and Londoners during the Second World War which remained generally positive, but the detail of that history is not the focus here (see Kelly 2013a, 333-334). 
practice, with its cultural cachet intact, is apparently perfectly integrated into English culture, into the English home and within reach of the abilities of the average English (later, British) cook. This 'simplicity' is a long way from Escoffier's nineteenth- and early-twentieth-century display and elaborate Savoy menus, but French gastronomy also retains its haute cuisine status as long as Raymond Blanc also prepares menus at Le Manoir aux Quat' Saisons, or Michel Roux Jnr, son and nephew of the two Roux brothers who opened Mayfair's Le Gavroche in 1967, continues their legacy in his restaurants while also producing cookery books for the wider British public and reaching a large audience as on TV programmes such as BBC's 'Masterchef - The Professionals' (2008-2013) and 'Food and Drink' (2013), continuing its very public display in multiple forms.

\section{French food and the French migrant in $21^{\text {st }}$ century 'global' London}

Viewing the migrant experience through the lens of food culture presents a new challenge in the contemporary period due to the explosion of world food available across London, which now pitches itself as a 'global city' and, of course, through accessibility via TV and many other media channels, cook books, blogs and websites, and the growth of 'foodie culture' in a British culinary landscape which is unrecognisable if compared to that of three decades ago:

The story of eating out in London holds a mirror to the changing wealth and social style of the city. There is much change; there is much continuity [...] London's infinite capacity for absorption and assimilation, its spirit of entrepreneurialism and its role in the world marketplace have filled Londoners' pocket and stomachs. Eating out

\footnotetext{
42 This emphasis on French food not being expensive is an important cultural insight and is one that contemporary French chefs in the British market use by operating across a range of restaurants and media. Mennell $(1985,1996)$ identifies attitudes towards economy prevalent in English writing on food, and 'one of the distinguishing marks of English culinary culture in comparison with the French' (190).
} 
is a fundamental part of the social, economic and cultural life of the capital (Thurley, $6)$.

From the second half of the twentieth century cuisines from around the world flourished in London, and still do, in increasing numbers and varieties. As Cathy Ross writes of the late twentieth century:

Eating out in London during the twentieth century can be seen as the maturing of trends that began in the nineteenth century. However change was on a more spectacular scale. London ends the twentieth century with the title 'Restaurant capital of the world', a city where eating out is the social norm for almost 7 million Londoners, all of whom, statistically, spend an average of $£ 700$ a year in the pursuit of pleasure through the productions of professional cooks. (Ross 1999b, 87)

Before the First World War, London's West End offered just a few German, one Chinese and one Indian restaurant alongside the French and Italian cuisines that dominated there. By World War Two, these had been joined by Greek, Turkish, Palestinian, Jewish, Russian, Spanish, Japanese, Brazilian, Hungarian and Egyptian, while now: 'Today's gastronomic network encompasses the globe' (Ross 1999b, 87-88). What is the place of French food, and of the French migrant in all of this? French gastronomy and cooking, and French influences, still flourish, from the established bourgeois cooking of Mon Plaisir in Monmouth Street, Covent Garden, opened in the $1940 \mathrm{~s},{ }^{43}$ to the haute cuisine served at Le Gavroche, Mayfair since 1967, although the evolving menus tell their own story. ${ }^{44}$

\footnotetext{
${ }^{43}$ The Mon Plaisir website claims it (incorrectly) to be 'London's oldest French restaurant' as 'a purveyor of the finest French cuisine for over half a century', and goes on to declare that 'the entente cordiale hits you as you
} 
There is also the arrival in London of Francophone cooking from North Africa, SubSaharan Africa, Lebanon and Vietnam which offer a diverse range of migrant experience to consider. There was already a North African restaurant, Le Petit Prince, in Kentish Town as far back as the early 1980s, even if the website of the much-acclaimed Momo restaurant and bar claims that when its founder Mourad Mazouz arrived in London in 1995: 'among the first things that he did was look for a place to eat his homely couscous', but he could not find one, and so opened his own.

Recently arrived French restaurants in London still often display their 'Frenchness', sometimes with few concessions to 'British' tastes, or sometimes combined with Englishness in intriguing ways for the study of migration, food, material culture and cultural exchange. Examples are Terroirs ${ }^{45}$ in King William IV Street, Covent Garden, which opened in late 2008. The concept which gives the restaurant its name is resolutely French, although they also serve natural wines ${ }^{46}$ from Spain, Portugal, Corsica, Italy and Sicily. As a further indicator of French food and the place of the French migrant in globalised London, observation shows that front-of-house staff are currently international. Another restaurant in their group retains the very English name of the former pub site it occupies in St Martin's Lane, the Green Man and French Horn, but specialises very specifically in Loire Valley food and wine, representing a symbol of Franco-British food culture exchanges in the twenty-first century.

Similarly, the Compagnie des Vins Surnaturels (CVS) has a wine bar in Neal's Yard, again in Covent Garden (food culture is also important in charting the evolving geography of

enter and the French atmosphere is as thick as the waiters' French accents'. The French migrant also has to contend with cliché and stereotype.

${ }^{44}$ See note 55 on this point.

${ }^{45}$ On the concept of 'terroir' see, for example, the recent work of Marion Demossier $(2011,2012)$.

${ }^{46}$ Natural wine is wine made without chemical and minimum technological intervention in growing grapes and making them into wine. The term is used to distinguish such wine from organic wine and biodynamic wine because of differences in cellar practices. All natural wines are, however, farmed organically at a minimum and many growers are biodynamic in the vineyard as well. 
'French London'), ${ }^{47}$ which opened in December 2013 with food that is 'French-inspired but [uses] British produce' on the menu, including 'Mountain Chicken', a dish of buttermilk-fried frogs' legs, which, with other ingredients and recipes that also endure from earlier times, recalls Madame Prunier's recommendation of frogs' legs. Their latest opening (April 2015) displays its 'Frenchness' with a name which translates rather awkwardly into English (they use 'happy mess') and is open to misunderstanding by those without a good knowledge of French: Le Joyeux Bordel - a confident linguistic intervention by a young generation of French restaurant entrepreneurs. As well as providing an indication of how French migrants in the restaurant sector position the business of French food - and themselves - in the globalised market of London, these enterprises again provide insight into the experience of the French migrant in twenty-first-century London. CVS female sommelier, Julia Oudill pointed out in a recent interview that she finds working in the UK far easier than her native France: 'In Paris, I had a lot of hostility; you're not taken seriously as a young woman. They would ask to see the sommelier. Even though I was one' (Mesure 2014). Oudill is part of a growing wave of women taking on the traditionally male-dominated role of wine waiter, and her experience of the perceived openness of London compared to Paris is echoed by young French migrants in all work sectors, from the professional, highly educated and highly skilled elite in the City of London to the more casual worker in Paul, the French-owned bakery and patisserie chain which has spread across London (Huc-Hepher and Drake, 2013).

On the world restaurant stage, French chefs still have enormous prestige (although they do not necessarily always now top the world restaurant 'league tables' but compete with arrivals such as the Catalans, Basques and Scandinavians), and it is important for a chef with global reach such as Joël Robuchon (Paris, Hong Kong, Las Vegas, Macao, Monaco,

\footnotetext{
${ }^{47}$ It is owned by The Experimental Group which also has the Experimental Cocktail Club in Gerrard Street, Soho (some London French geography remains the same, this time with an English language name). There is also a Compagnie des Vins Surnaturels wine-bar in Paris in St-Germain-des-Près, rue Lobineau.
} 
Singapore, Taipei, Tokyo) or Alain Ducasse (Paris, New York, Monaco, Gstaadt, Tokyo, Las

Vegas, Beirut, Hong Kong, Mauritius) to have a restaurant in London, while Hélène Darroze at the Connaught (a place with historical French resonance) since 2008 is notable as a female chef with international reach. 'French' still sells in the restaurant world despite concurrent French anxiety concerning the place of France and French culture in a globalised world. ${ }^{48}$ However, the most ostensibly 'French' may not be French, or French in origin, at all. This phenomenon is a further essential element in understanding the experiences, and the perceptions by the host culture, of the French migrant in London and of how 'French' culinary knowledge and capital is displayed. The Café Rouge chain describes itself, for example, as 'a taste of France', offering 'authentic Parisian bistro culture [and] inimitable French hospitality style in over 100 locations across Britain' (websites) founded by the very un-French-named Roger Myers and Karen Jones in 1989, owned now by the Tragus Group (operating also Bella Italia and Strada). Café Rouge luxuriates in a fantasy French bistro experience, as does on a smaller scale Brasserie Zedel, opened by the owners of the Wolsey and the Delaunay, and yet another newer chain, Côte, which is 'inspired by new trends in Paris $[\ldots]$ dedicated to serving authentic dishes with a modern twist [...] on the menu are brasserie favourites such as steak frites and tuna Niçoise' (website). Luc Dubanchet, founder of the French food magazine Omnivore, talking about the generally well-received Brasserie Zedel in London, notes the irony: 'There are so many French copies. Even here in France there are French copies. Why another one? [...] You have to be careful you don't get too complacent. Otherwise, you will wake up and find that you're, well, French' (Harries 2012). 49

\footnotetext{
48 This is portrayed and parodied by Michel Houllebecq's Goncourt Prize novel, La Carte et le territoire, 2010. Sincere thanks to Ruth Cruickshank, Royal Holloway University of London for pointing out this out to me and for our early discussions about representations of French gastronomy in the twenty-first-century global market. ${ }^{49}$ Luc Dubanchet is the founder of Omnivore, which describes itself as ' $100 \%$ jeune [young] cuisine', and there are to date also four editions of the Omnivore Food Book; these proclaim themselves as 'born of the observation,
} 
However, the apparently French is big business in the UK - and this adds a layer of complexity to the realities of 'being French' in London. Côte was launched in 2007 by Andrew Bassdone and Chris Benians (formerly of Caprice Holdings, Bassdone also developed Strada restaurants), has some 45 UK sites and is owned by a private equity company. ${ }^{50} \mathrm{~A}$ further example is the owners of the critically acclaimed Arbutus (Soho) and Wild Honey (Marylebone) going on to open the very French-named and -styled 'Parisianinspired brasserie' Les Deux Salons, again in King William IV Street, Covent Garden, which is near Terroirs, and which has taken on an even more French identity since being acquired by Prescott and Conran. ${ }^{51}$

On the other hand, in twenty-first-century London the apparently not French may be French-owned. For example Bordeaux-born Bruno Loubet's Grain Store in newly redeveloped King's Cross is a very different venture to his earlier Bistro Bruno in Soho (1993-1995) and to his current Bistro Bruno Loubet in Clerkenwell, a restaurant which fully displays its 'Frenchness'. Grain Store and the Bistro together say much about the French migrant and French gastronomy in globalised London. Historically, French restaurants and restaurant sites have always evolved in London, with and without French restaurateurs: one example is the La Tour Eiffel at 1 Percy Street, Fitzrovia. It began in 1908 as a French restaurant run by an Austrian chef, Rudolph Stulik, and was notably the meeting place for the Imagist poets, Wyndham Lewis and the Vorticists - with a private dining room decorated by Wyndham Lewis in 1915 - and for others of London's avant-garde. It then became London's leading Greek restaurant and by 1999 was Bam Bou, a French-Vietnamese restaurant with a

around the year 2000, that French gastronomy was no longer really anywhere [...] It lacked imagination, was too certain in its achievements and too sure of itself' (publication websites).

${ }^{50}$ Private equity has long been in love with the restaurant business: 'you can't eat out on-line', they say.

${ }^{51}$ Re-opened by Prescott and Conran in June 2015; on 14 July 2015 it celebrated 'La Fête Nationale'; in August 2015 the restaurant proposed a 'French getaway' with summer dishes of southern France; it invited diners to 'have [yourself] a very French Christmas; 'tis the season to be jolly.... and French!' during 'la période des fêtes' in 2015; in January 2016 it offered the 'Galette des Rois'; each Sunday it proposes 'le déjeuner du dimanche en famille'. 
Parisian-trained chef serving a menu of globally influenced Asian dishes with an international wine list: 'No 1 Percy Street offers two broad conclusions about the last hundred years. First, change has been intimately bound up with the immigrant tale; and secondly, change in eating out mirrors the unprecedented social, cultural and economic shifts that the century has seen' (Ross 1999b, 100). The experiences of French gastronomy and of the French migrant in London have necessarily evolved with these changes.

\section{The French Migrant and French Gastronomy in London}

The French can therefore be considered highly 'visible' in London in terms of a material culture exemplified in food knowledge and the restaurant experience; indeed, theirs is an identity often adopted by others who are not French. In the metropolitan, multicultural city, the French still frequently make themselves known by their gastronomic culture and are often 'known' by it even if in the global marketplace of twenty-first-century London, gastronomic identities are commercially and socially shape-shifting.

Nonetheless, ambiguities persist around these French migrants, and about their contributions to and impact on London. As noted previously, France is considered by some observers to be currently experiencing some kind of identity and cultural confidence crisis, along with its economic crisis in the global recession, clinging to traditions and to a way of life, and considered by some to be thinking that it has more to lose than to gain by change. This may well be a generational attitude; there is plenty of evidence of a vibrant youth culture in Paris (and elsewhere in France) from art to music to food - with the new 'bistronomie' and 'Le Fooding', for example, despite the mixed reception which they sometimes receive, particularly inside France. ${ }^{52}$ One thing that such movements do highlight is that food culture

\footnotetext{
52 The concept of 'Bistronomie', a portmanteau of 'bistrot' and of 'gastronomy', represents a move away from classic haute cuisine towards fine cooking (often a more experimental type of cooking and with more 'global', especially Asian/Japanese, flavours than traditional French gastronomy), offered in relaxed surroundings and at
} 
is also political culture in France. As the American journalist and cultural and culinary commentator Adam Gopnik has observed, at times Le Fooding 'appears determined to wrench the entire culture of good food in France from its historic place, on the nationalist right, to a new home, in the libertarian center' (Gopnik, 2010). ${ }^{53}$ In London, the 'French copies' (often not French in origin) derided by Luc Dubanchet, the style that has been mechanically copied over and over according to Alexandre Cammas of 'Le Fooding', thrive, together with the newer culinary culture and attitudes which shake the complacency of being 'too French'. The presence of the French migrant is apparent in both displays of French gastronomy. ${ }^{54}$

For centuries London has provided a place of refuge and/or opportunity to very different French men and women from across the political spectrum, of differing religious and social beliefs, and from different social classes. Across the places and spaces of London, the sites of the London French continue to evolve, and food - what, where, how it is produced, sold, bought, prepared and consumed, and by whom - is a key site for understanding the relationship between French migrant identity and a French material culture displayed in culinary knowledge. Food plays a significant role consistently throughout migration history, and its specific agency varies with shifting historical and political conditions. Migrants wish to eat the food of their homelands and in many patterns of

more affordable prices. Places serving this kind of cooking are often to be found in areas of Paris now fashionable with a younger clientele (for example the $10^{\text {th }}$ and $11^{\text {th }}$ arrondissements). 'Le Fooding', combining 'food' with 'feeling' is an annual food guide (print, on-line, app) which again began in 2000, and which departs from what it sees as the gastronomic status quo of French food; it champions a 'liberation' from traditional codes and conventions to give chefs the possibility of more self-expression in more contemporary food, although it also focuses on the experience of consumers. Founded by Alexandre Cammas and Emmanuel Rubin, French journalists and food critics, it often receives more praise (seen as reinventing the French culinary scene) outside France than within it. Cammas says he liked the 'provocation' of using an English word within the context of French cuisine (Gopnik, 2010, discerns more of an 'Americanization' in the movement without it becoming American, and uses the analogy of French New Wave cinema).

${ }^{53}$ Adam Gopnik lived with his family for five years in Paris as documented in his series of essays Paris to the Moon, 2000, and is also the author of The Table Comes First: France, Family and the Meaning of Food, 2011.

${ }^{54}$ Conversely in Paris, it is young migrant American, British, Australian and Japanese chefs who are currently renewing French cuisine and its reputation. See, for example, Michael Steinberger, 'Can anyone save French food?' New York Times, 28 March, 2014. I am again grateful to Ruth Cruickshank for drawing my attention to this article. Steinberger is the author of Au Revoir to All That: Food, Wine and the End of France, 2010. 
migration they establish shops to supply them and places to eat them; as they become settled and new generations are born, these foods are frequently adapted to the foods of the host culture and other neighbours (Panayi, 9). The pattern of French cuisine in London is a rather different one. There is an enormous distance travelled from the dominance of French food in nineteenth-century London, mediated to the English élites by a very specific set of cooks and chefs, to its multi-faceted identities in twenty-first-century multicultural London. What has changed for the French - and now Francophone - migrant, and what has remained the same? In the display of French gastronomy in the British capital, 'Frenchness' veers between cliché and renewal. It fights for a place with other food traditions and forms of culinary knowledge that are taken up in the eclectic culture of twenty-first-century London - the popularity of Japanese and Asian cooking, the evolution and current prominence of Spanish, Catalan and Basque food - to give but two examples. Indeed, French food in London and elsewhere may appear to be under siege by increased internationalisation. Examining the intersection between the changing nature of the place of French food in the British capital, and the changing experiences of the migrants associated with it, broadens understanding of conceptions, experiences and perceptions of migration, migrant identities and reciprocal cultural exchanges more generally. However, the restaurant, and the relationship to food more generally, is a complex site of power relations, of taste, of social and personal esteem, of tradition, of cultural habit, of rites and rituals and of modes of behaviour strictly codified in both migrant and host culture, of social control, of public identity, of seeing and being seen, of new experiences (and some fear of these). The restaurant is, as contemporary restaurateur Ruth Rogers, chef proprietor of London's River Café, says, ‘[a place where] people [do] very private things in a very public space' (Rogers 2015). There are social inequalities and social distinctions at play, expectations associated with educational and occupational practice, complex emotional interactions between purveyors and consumers of 
food, and economic and social implications in the practice of eating out which is both a form of 'entertainment' and leisure and an expression of taste and status (Warde and Martens, 1, 69-70). The social activity of cooking, and especially of dining out, is replete with displays of knowledge - both culinary and linguistic - and of cultural literacy. ${ }^{55}$ While the explicit cultural capital of those associated with culinary knowledge and gastronomy may inflect British perceptions of French migrants and their own perceptions of themselves, this does not make necessarily for a more 'comfortable' migratory experience. The French migrant who operates in this space of socially and politically charged activity is required to negotiate a space of complex meanings and relationships.

\section{Works Cited}

Aron, Jean-Paul. Le Mangeur du XIXe siècle. Paris: Robert Laffont, 1973. Print.

Ashley, Bob, Joanne Hollows, Steve Jones, and Ben Taylor. Food and Cultural Studies. London: Routledge, 2004. Print.

Atkin, Nick. The Forgotten French: Exiles in the British Isles, 1940-44, Manchester and New York: Manchester University Press, 2003. Print.

Bantman, Constance. "“Almost the only free city in the world": mapping out the French anarchist presence in London, late 1870s-1914'. A History of the French in London: Liberty, Equality, Opportunity. Eds. Debra Kelly and Martyn Cornick. London: IHR publications, 2013. 193-215. Print.

\footnotetext{
55 The issue of the language of culinary knowledge and the development of menus is a fascinating one, and a full discussion of evolving French culinary terminology in London will be a focus of a chapter in the forthcoming monograph based on this research. I acknowledge and thank the anonymous reviewer of the first version of this article for insisting on this point. As was noted, the role of the French language in London's culinary world is an essential factor in France's influence that arguably supersedes that of the individual dishes that come and go. Many people in England could read the French terminology of menus in the early twentieth century (relating to the teaching of French at home and schools). The role of the French language in more recent food history is also part of this story (for example 'Le fooding') in the context of the French language's role in the continuing shifts in gastronomy worldwide. And although disputed, and featuring more 3-star restaurants in Japan than in France, the Michelin Guide is French indicating a continuing presence in the language and aesthetics of the restaurant world.
} 
Barthes, Roland. L'Empire des signes. Paris: Gallimard, 1970. Print.

Blanc, Raymond. Simple French Cookery (Step by step to everyone's favourite French recipes). London: BBC Books, 2002. Print.

Boulestin, Marcel. Simple French Cooking for English Homes. London: Quadrille, [1923] 2011. Print.

Bourdieu, Pierre. Distinction: A Social Critique of the Judgement of Taste. Cambridge: Harvard University Press, 1984. Print.

Bowden, Gregory Houston. British Gastronomy. The Rise of the Great Restaurants. London: Chatto and Windus, 1975. Print.

Braudel, Fernand. Civilisation matérielle, économie et capitalisme. Paris: Armand Colin, 1979. Print.

Brillat-Savarin, Jean Anthelme. La Physiologie du gout. Paris: Sautelet, 1825. Print.

Burnett, John. England Eats Out: A Social History of Eating Out in England from 1830 to the present. London: Routledge, 2004. Print.

Caplan, Pat. Food, Health and Identity. London: Routledge, 1997. Print.

Chevrier, Francis. Notre gastronomie est une culture. Paris: François Bourin, 2011. Print.

Cooper-Richet, Diana and Michel Rapoport. L'Entente Cordiale: cents ans de relations culturelles franco-britanniques, 1904-2004. Paris: Créaphis, 2006. Print.

David, Elizabeth. French Country Cooking. London: John Lehmann Ltd., 1951. Print.

David. Elizabeth. French Provincial Cooking. London: Michael Joseph, 1960. Print.

Demossier, Marion. 'Beyond Terroir: territorial construction, hegemonic discourse and French wine culture.' Journal of the Royal Anthropological Institute 17.4 (2011): 685-705. Print. 
Demossier, Marion. 'The Europeanization of Terroir: consuming place, tradition and authenticity.' European Identity and Culture. Narratives of Transnational Belonging. Eds. Rebecca Friedman and Markus Thiel. Farnham: Ashgate, 2012. 119-136. Print.

Driver, Christopher. The British at Table 1940-1980. London: Chatto and Windus; The Hogarth Press, 1983. Print.

Ehrman, Edwina. '19 $19^{\text {th }}$ Century.' London Eats Out. 500 years of capital dining. London: Museum of London and Philip Wilson Publishers, 1999. 68-85. Print.

Elias, Norbert. The Civilising Process [1939]. Vol I: The History of Manners. Oxford: Basil Blackwell, 1978. Print.

Ferguson, Priscilla Parkhurst. Accounting for Taste: The Triumph of French Cuisine. Chicago: University of Chicago Press, 2004. Print.

Fine, Gary Alan. Kitchens. The Culture of Restaurant Work. Berkeley: University of California Press, (1996), 2009. Print.

Fisher, F. J. 'The Development of London as a Centre of Conspicuous Consumption in the Sixteenth and Seventeenth Centuries', Transactions of the Royal Historical Society, 4th series, vol. 30 (1948): 37-50. Print.

Forsyth, Hazel. ' $17^{\text {th }}$ century.' London Eats Out. 500 years of capital dining. London: Museum of London and Philip Wilson Publishers, 1999. 30-49. Print.

Francatelli, Charles Elmé. The Modern Cook. London, 1845. Print.

Gibson, Robert. Best of Enemies: Anglo-French Relations since the Norman Conquest (1995). London: Impress Books, 2004. Print.

Glasse, Hannah. The Art of Cookery Made Plain and Easy. London, 1747. Print.

Gopnik, Adam. 'No Rules! Is Le Fooding, the French culinary movement, more than a feeling?' Annals of Gastronomy, April 5, 2010. Web. 
Grimod de la Reynière, Alexandre. (Ed.) Almanach des Gourmands. Paris: Maradan, 18031812. Print.

Harries, Rhiannon. 'Bistronomie', Independent on Sunday, 7 October 2012. Web.

Henrey, Robert (Mrs). The Siege of London. London: Temple Press, 1946. Print.

Hooton-Smith, Eileen. The Restaurants of London. London: Alfred E. Knopf, 1928. Print.

Houllebecq, Michel. La Carte et le territoire. Paris: Flammarion, 2010. Print.

Huc-Hepher, Saskia and Helen Drake. 'From the 16ème to South Ken? A study of the contemporary French population in London.' A History of the French in London: Liberty, Equality, Opportunity. Eds. Debra Kelly and Martyn Cornick. London: IHR Publications, 2013. 391-429. Print.

Humble, Nicola. Culinary Pleasures. Cookbooks and the Transformation of British Food. London: Faber and Faber, 2004. Print.

James, Kenneth. Escoffier. The King of Chefs. London: Hambledon and London, 2002. Print.

Kelly, Debra. 'Mapping Free French London: places, spaces, traces.' A History of the French in London: Liberty, Equality, Opportunity. Eds. Debra Kelly and Martyn Cornick. London: IHR Publications, 2013a. 303-341. Print.

Kelly, Debra. 'Conclusion: a temporal and spatial mapping of the French in London.' $A$ History of the French in London: Liberty, Equality, Opportunity. Eds. Debra Kelly and Martyn Cornick. London: IHR Publications, 2013b. 431-447. Print.

Kelly, Debra and Martyn Cornick. A History of the French in London: Liberty, Equality, Opportunity. London: IHR Publications, 2013. Print.

Kelly, Ian. Cooking for Kings: the Life of Antonin Carême, the First Celebrity Chef. London: Short Books, 2003. Print.

Kershen, Anne. Food in the Migrant Experience. London: Ashgate, 2002. Print. 
Kershen, Anne. Strangers, Aliens and Asians: Huguenots, Jews and Bangladeshis in Spitalfields, 1600-2000. London: Routledge, 2005. Print.

Mars, Valerie. 'Experiencing French cookery in nineteenth century London.' A History of the French in London: Liberty, Equality, Opportunity. Eds. Debra Kelly and Martyn Cornick. London: IHR Publications, 2013. 217-240. Print.

Mennell, Stephen. All Manners of Food. Eating and Taste in England and France from the Middle Ages to the Present. Urbana and Chicago: University of Illinois Press (1985), 1996. Print.

Mesure, Susie. 'Move over, men of the wine world, and make way for the sommelière'. The Independent on Sunday, 1 June 2014. Web.

Mitchell, W.J.T. 'Showing seeing: a critique of visual culture', Journal of Visual Culture, Vol. 1 (2), 2002. 161-181. Print.

Newnham-Davis, Nathaniel. Dinners and Diners: Where and How to Dine in London. London: Grant Richards, 1899. Print.

Nora, Pierre. (Ed.) Les Lieux de mémoire. (3 vols.). Paris: Gallimard, 1992. Print.

Norman, Jill. Introduction. Madame Prunier's Fish Cookery Book. By Simone Prunier. London: Quadrille, 2011. vi-viii. Print.

Onfray, Michel. La Raison gourmande. Paris: Grasset, 1995. Print.

Ory, Pascal. 'La Gastronomie.' Les Lieux de mémoire. Ed. Pierre Nora. Paris: Gallimard, 1992. Tome III, vol. 2, 823-853. Print.

Ory, Pascal. Le Discours gastronomique français des origines à nos jours. Paris: Gallimard / Julliard, 1998. Print.

Panayi, Panikos. Spicing up Britain. The Multicultural History of British Food. London: Reaktion Books, 2008. Print. 
Pitte, Jean-Robert. Gastronomie française. Histoire et géographie d'une passion. Paris: Fayard, 1991. Print.

Prunier, Simone. Madame Prunier's Fish Cookery Book. London: Quadrille, [1938] 2011. Print.

Prunier, Simone. La Maison: the History of Prunier's. London: Longman, Green and Co., 1957. Print.

Rambourg, Patrick. Histoire de la cuisine et de la gastronomie françaises du moyen âge au XXe siècle. Paris: Perrin, 2010. Print.

Rapoport, Michel. 'The London French from the Belle Epoque to the end of the inter-war period (1880-1939).' A History of the French in London: Liberty, Equality, Opportunity. Eds. Debra Kelly and Martyn Cornick. London: IHR Publications, 2013. 241-279. Print.

Rogers, Ruth. 'Desert Island Discs', BBC Radio 4, 2 August 2015. Radio.

Ross, Cathy. 'Introduction. Five centuries of city food.' London Eats Out. 500 years of capital dining. London: Museum of London and Philip Wilson Publishers, 1999a. 811. Print.

Ross, Cathy. '20 th Century.' London Eats Out. 500 years of capital dining. London: Museum of London and Philip Wilson Publishers, 1999b. 86-103. Print.

Saillard, Denis. 'La cuisine de l'autre. Echanges et rivalités dans les relations gastronomiques franco-anglaises du XVIIIe siècle à nos jours'. Nos meilleurs ennemis. L'Entente culturelle franco-britannique revisitée, sous la direction de Diana Cooper-Richet et Michel Rapoport, Paris: Atlande, 2014.101-129. Print.

Simon, André. History of the Champagne Trade in England. London: Wyman, 1905. Print.

Simon, André. Les Pauvres de France en Angleterre. London: Duckworth, 1919. Print.

Soyer, Alexis. The Modern Housewife. London: Simkin, Marshall \& Co., 1849. Print. 
Soyer, Alexis. A Shilling Cookery for the People. London: Geo. Routledge \& Co., 1854. Print.

Steinberger, Michael. Au Revoir to All That: Food, Wine and the End of France. New York: Bloomsbury, 2010. Print.

Thurley, Simon. 'Foreword.' London Eats Out. 500 years of capital dining. London: Museum of London and Philip Wilson Publishers, 1999. 6-7. Print.

Tombs, Robert and Isabelle Tombs. That Sweet Enemy: the French and the British from the Sun King to the Present, London: Heinemann, 2006. Print.

Villars, P. 'The French.' Living London. Its work and its play, its humour and its pathos, its sights and its scenes. Ed. George R. Sims. London: Cassell, 1901. Vol II, 133-138. Print.

Warde, Alan and Lydia Martens. Eating Out. Social Differentiation, Consumption and Pleasure. Cambridge: Cambridge University Press, 2000. Print.

Zulkin, Sharon. Landscapes of Power. Berkeley: University of California Press, 1991. Print. 